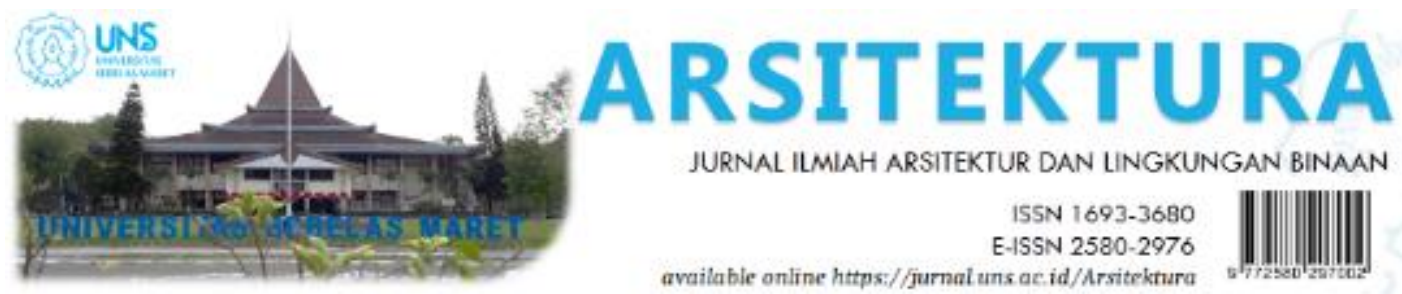

Volume 19 Issue 2 October 2021, pages: 263-274

\title{
Evaluasi Terhadap Penerapan Desain Aksesibilitas Untuk Disabilitas Fisik di Fakultas Industri Kreatif Universitas Telkom
}

\section{Accessible Design analysis for Physical Disabilities in Faculty of Creative Industry, Telkom University}

\author{
Widyanesti Liritantri ${ }^{1 *}$, Andreas Dwiputro Handoyo ${ }^{2}$, Kristal Puan Bazukarno ${ }^{3}$, Leandro \\ Krista Arnita 4 \\ Prodi Design Interior, Universitas Telkom Bandung ${ }^{1 *}$ \\ deny.setya.afriyanto@mail.ugm.ac.id \\ Prodi Design Interior, Universitas Telkom Bandung ${ }^{2}$ \\ Prodi Design Interior, Universitas Telkom Bandung ${ }^{3}$ \\ Prodi Design Interior, Universitas Telkom Bandung ${ }^{4}$
}

DOI: https://doi.org/10.20961/arst.v19i2.50841

Received:April30,2021 Revised:September22,2021 Accepted:September29,2021 Available online:October30,2021

\begin{abstract}
To have an education is the right of Indonesian citizens, including persons with disabilities. Likewise, it is stated in Ministry of PUPR Article 10 of Law no. 8/2016 and from Article 5 of the Regulation of the Menristekdikti 2017, where university have to provides facilities and infrastructure according to the needs of students with special needs. The Lack of the facilities for disabled person in the higher education, caused only $5 \%$ from 10,8 million with dissabilities gain degree from the universities. Therefore, Telkom University as an institution need to consider in providing higher education that can meet this needs. This research is expected to provide an overview for the development of design accessibility at the FIK Telkom University campus for them to get in the future. The method used is qualitative descriptive approach. The result is FIK Telkom university have not meet the standard from Persyaratan Kemudahan bangunan Gedung PUPR and also ADCET. Whether Telkom University wants to be an inclusive campus, the university have put big effort in the inter-way access and also the inter-floor access, and most of the facilities needed to be improved considering to providing all facilities for the student with special needs.
\end{abstract}

Keywords: accessible design; physical disabilities; inclusive campus

\section{PENDAHULUAN}

Penyandang Disabilitas di Indonesia harus berjuang keras untuk memperoleh kesempatan dalam mengakses pendidikan tinggi, sedangkan mereka mempunyai hak untuk mengikuti proses pendidikan di perguruan tinggi. (Kementrian PUPR, 2016).
Minimnya fasilitas untuk para penyandang disabilitas mendapatkan pendidikan tinggi yang menyebabkan dari 10.8 juta penyandang disabilitas hanya $5 \%$ yang lulus kuliah (Dzulfikar, 2019). Bahkan dipertegas lagi bahwa Universitas yang menyediakan fasilitas untuk penyandang disabilitas hanya ada 5 dari 4500 Universitas dan Perguruan Tinggi di Indonesia. 
The number of Indonesian universities with special needs units has been revised from "very few" to a more specific number, "only around five”. (Dzulfikar, 2019)

Fasilitas kampus yang memenuhi hak aksesibilitas disabilitas menurut Peraturan Menteri Riset, Teknologi dan Pendidikan Tinggi (Permenristekdikti) No: 44 Tahun 2015 Tentang Standar Nasional Pendidikan Tinggi pada pasal 37 disebutkan, yaitu: Ayat (1) Perguruan tinggi harus menyediakan sarana dan prasarana yang dapat diakses oleh mahasiswa yang berkebutuhan khusus. Ayat (2) Sarana dan prasarana sebagaimana dimaksud pada ayat (1) terdiri atas: a. pelabelan dengan tulisan Braille dan informasi dalam bentuk suara; b. lerengan (ramp) untuk pengguna kursi roda; c. jalur pemandu (guiding block) di jalan atau koridor di lingkungan kampus; d. peta/denah kampus atau gedung dalam bentuk peta/denah timbul; dan e. toilet atau kamar mandi untuk pengguna kursi roda. Ayat (3) pedoman mengenai sarana dan prasarana bagi mahasiswa yang berkebutuhan khusus sebagaimana dimaksud pada ayat (2) di tetapkan oleh Direktur Jendral Pembelajaran dan Kemahasiswaan.

Kriteria kampus ramah disabilitas harus meliputi aktivitas akademik, non-akademik, interaksi sosial, sarana prasarana akademik, sarana prasarana manajemen, sarana prasarana penunjang, desain, kondisi sosial, aksesibilitas fisik, aksebilitas informasi, kelembagaan kampus, dan peran pemerintah (Hikmah, et.al, 2020)

Untuk menjadi kampus yang ramah disabilitas dalam memenuhi hak akses disabilitas yang sesuai dengan peraturan Permenristekdikti, yang perlu diperhatikan yaitu (1) Apakah di dalam lingkungan institusi Telkom university telah memiliki fasilitas khusus bagi mahasiswa penyandang disabilitas? (2) Dari segi dimensi dan kebutuhan, apakah dapat dibuat sesuai dengan kebutuhan-kebutuhan penyandang disabilitas?

Adapun Tujuan dilakukannya penelitian ini untuk mengetahui aksesibilitas pada kampus yaitu akses antar ruangan dan antar lantai, mengetahui fasilitas pendukung yang digunakan untuk mempermudah proses pembelajaran bagi penyandang disabilitas, di
Fakultas Industri Kreatif dan di lingkungan universitas, Mengetahui apa saja yang sudah bisa dianggap mendukung dan apa saja yg bisa memenuhi kebutuhan dan juga mengetahui fasilitas yang dibutuhkan mahasiswa penyandang disabilitas untuk memenuhi kegiatan belajar. Dan diharapkan dengan adanya penelitian ini dapat bermanfaat sebagai referensi untuk menciptakan kampus yang ramah disabilitas

\subsection{Pengertian Disabilitas}

Definisi penyandang disabilitas adalah setiap orang yang mengalami keterbatasan fisik, intelektual, mental, dan/atau sensorik dalam jangka waktu lama yang dalam berinteraksi dengan lingkungan dapat mengalami hambatan dan kesulitan untuk berpartisipasi secara penuh dan efektif dengan warga negara lainnya berdasarkan kesamaan hak (Kementrian Kesehatan Republik Indonesia, 2019).

Ragam penyandang disabilitas meliputi penyandang disabilitas fisik, intelektual, mental, dan/atau sensorik, yang dapat dialami secara tunggal, ganda, atau multi dalam jangka waktu lama yang ditetapkan oleh tenaga medis sesuai dengan ketentuan peraturan perundangundangan.

Melihat dari pengertian dan jangkauan liputan dari penyandang disabilitas, yang akan lebih diteliti pada penelitian ini terbatas pada aksesible desain untuk penyandang disabilitas fisik.

\subsection{Kegiatan Belajar Penyandang Disabilitas}

Aksesibilitas adalah hal yang penting bagi penyandang disabilitas, untuk mewujudkan kesetaraan dan kesempatan untuk mendapatkan kesempatan seperti hal nya mahasiwa tanpa disabilitas. Aksesibilitas merupakan kemudahan yang disediakan untuk penyandang disabilitas dalam hal ini mendapatkan persamaan kesempatan dalam mendapatkan pengajaran.

Untuk mewujudkan aksesibilitas yang baik untuk penyandang disabilitas di pergururan tinggi yang dijadikan bahan acuan adalah dari pemerintah Australia yang mempunyai tingkat kemajuan dalam waktu 5 tahun dimana 
enrollment mahasiswa dengan disabilitas naik sebanyak $53.6 \%$ (ADCET, 2019).

Hal Positif dari pemerintah dan universitas di Australia bisa kita jadikan pedoman apa saja yang harus diperhatikan untuk mencapai perguruan tinggi yang ramah atau mendukung penyandang disabilitas. Menurut pemerintah Australia dengan peraturannya yang harus diperhatikan adalah bagian mana saja yang harus diperhatikan dalam mendukung aksesibilitas di dalam Kampus. Di Australia sendiri audit dibutuhkan oleh institusi untuk mengidentifikasi isu aksesibilitas di Kampus, dimana lebih berfokus kepada standar bangunan gedung. Ada 11 pertimbangan utama yang dipakai oleh Australian Disability Clearinghouse on Education and Training sebagai acuan dasar yang harus disediakan dalam hal aksesibilitas. (ADCET, 2019)

\subsection{Regulasi Dan Standar Ukuran Dimensi Dan Keamanan Fasilitas Untuk Penyandang Disabilitas}

Mengikuti regulasi dari pemerintah tentang Penerapan Prinsip Desain Universal Dan Penggunaan Dasar Ruang Yang Memadai, dimana harus memenuhi persyaratan kemudahan hubungan horizontal antar ruang (Kementrian Pekerjaan Umum Dan Perumahan Rakyat, 2017).

Sarana Hubungan horizontal antar ruang yang meliputi, pintu, selasar, koridor. jalur pedestrian, jalur pemandu dan jembatan penghubung antar ruang. Pintu geser otomatis merupakan pintu yang paling memenuhi kriteria kemudahan, keselamatan dan kemandirian (Jefri, 2016).

Untuk pintu dengan persyaratan ukuran bukaan minimal $90 \mathrm{~cm}$.

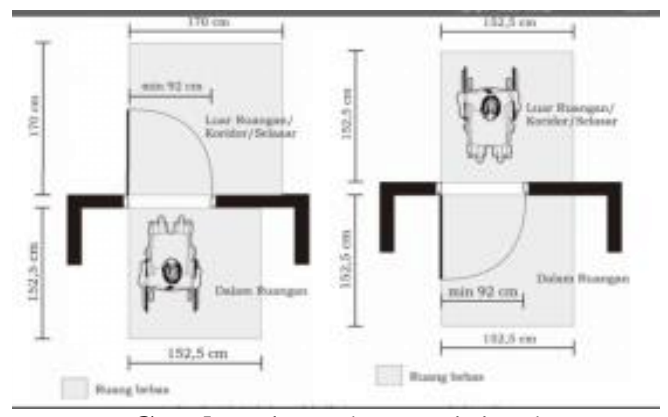

Gambar 1. Bukaan Minimal

Sumber: Persyaratan Kemudahan bangunan Gedung PUPR. Jakarta, 2016.
Untuk selasar harus memiliki lebar efektif yang cukup untuk dilewati oleh pengguna kursi roda atau 2 orang berpapasan paling sedikit $140 \mathrm{~cm}$.

Untuk koridor harus memiliki lebar efektif yang cukup untuk dilewati oleh 1 orang pengguna kursi roda paling sedikit $92 \mathrm{~cm}$.

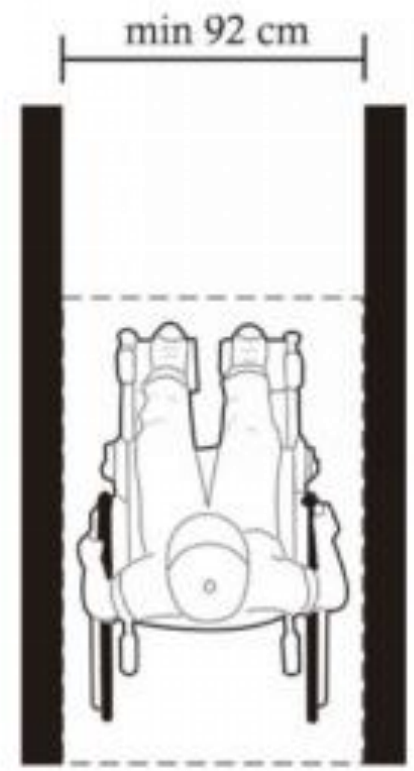

Gambar 2. Luas koridor minimal

Sumber: Persyaratan Kemudahan bangunan Gedung PUPR. Jakarta, 2016.

Hubungan vertical antar ruang meliputi tangga, dan lift, untuk tangga jika memungkinkan bisa ditambahkan dengan lift tangga (stairway lift)

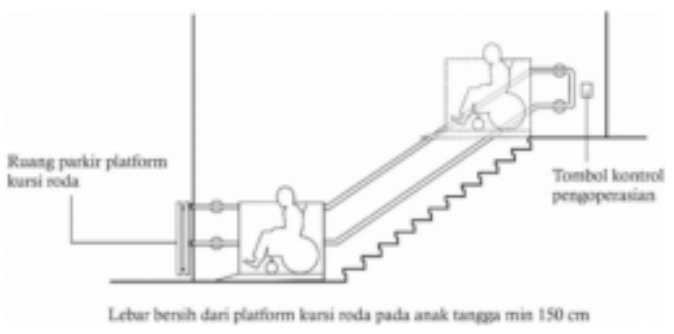

Gambar 3. Stairway Lift

Sumber: Persyaratan Kemudahan bangunan Gedung PUPR. Jakarta, 2016.

Untuk Fasilitas service seperti toilet standar ukuran minimalnya adalah $227.5 \mathrm{~cm}$ x 152,5 $\mathrm{cm}$. Ketinggian kloset harus sesuai dengan ketinggian pengguna kursi roda adalah 45-50 $\mathrm{cm}$. Letak tissu dan kran air dipasang disesuaikan agar mudah digunakan oleh mahasiswa disabilitas (Aziz, 2014) 


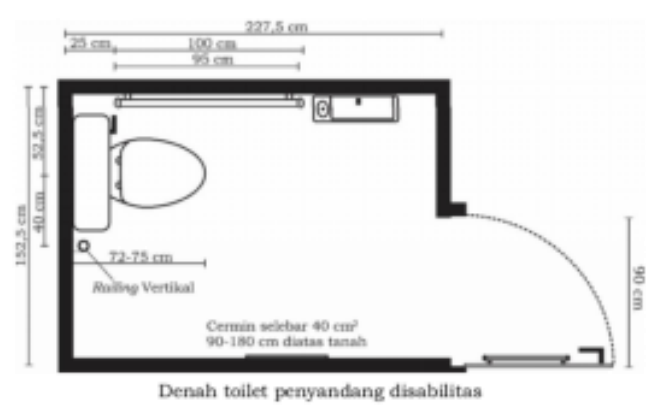

Gambar 4. Denah Toilet

Sumber: Persyaratan Kemudahan bangunan Gedung PUPR. Jakarta, 2016.

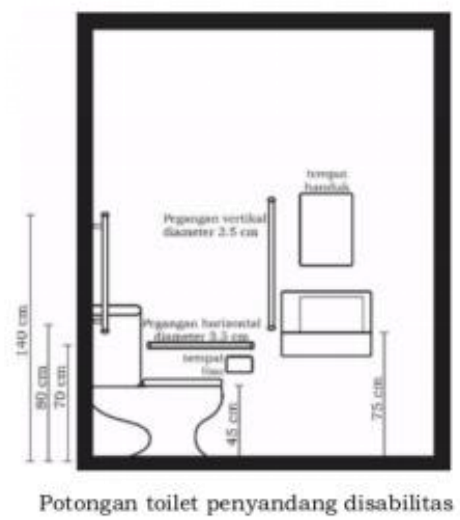

Gambar 5. Gambar Potongan Toilet

Sumber: Persyaratan Kemudahan bangunan Gedung PUPR. Jakarta, 2016.

Untuk Fasilitas pendukung pembelajaran yang terpenting adalah penggunaan meja yang bisa disesuaikan ketinggiannya, selain luasan untuk akses pengguna kursi roda. Standar minimum ketinggian meja untuk pengguna kursi roda sekitar $70-86 \mathrm{~cm}$.

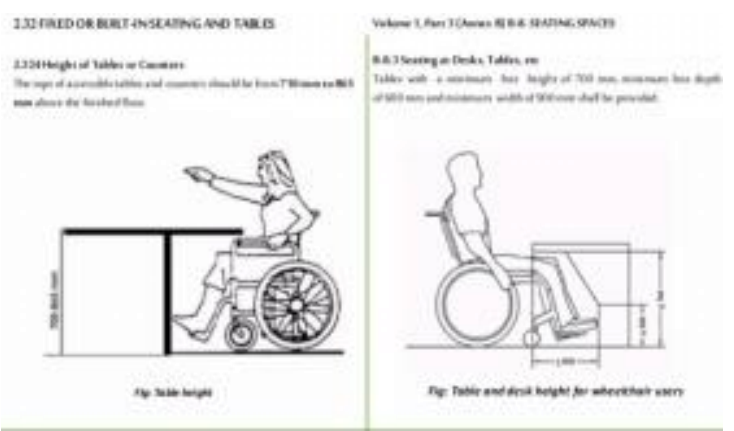

Gambar 5. Standar meja untuk pengguna kursi roda

Sumber: Dissability Friendly Manual, ADA, 2018

\section{METODE}

Metode Penelitian yang digunakan adalah metode Kualitatif deskriptif dan Kuantitatif.
Dimana pengumpulan data akan dilakukan melalui observasi dan survey lapangan di lokasi penelitian utama yaitu di Fakultas Industri Kreatif, Telkom University. Observasi melalui pengamatan meliputi aksesibilitas vertical dan horizontal/antar lantai, material interior dan furniture yang digunakan, mobilisasi, dan faktor lainnya yang menjadi syarat pemenuhan kebutuhan penyandang disabilitas. Tehnik pengumpulan meliputi data primer dan sekunder. Data primer didapatkan ketika survey dengan quesioner yang di sebarkan khusus untuk para penyandang disabilitas fisik untuk mendapatkan data kebutuhan yang paling sesuai dalam pemenuhan fasilitas untuk belajar dan mobilisasi, sedangkan data sekunder berupa studi literatur bersumber dari buku, jurnal dan literatur tentang desain aksesibilitas sebagai acuan. Selain dari observasi dan survey lapangan di lokasi utama, dilakukan juga kunjungan studi banding pada gedung perguruan tinggi lain yang telah menerapkan interior desain yang memfasilitasi penyandang disabilitas. Dari hasil observasi data dibandingan dengan 11 pertimbangan utama dari ADCET, dan dari hasil ini di kuatkan dengan survey yang dilakukan kepada penyandang disabilitas fisik fasilitas yang menurut mereka paling sesuai untuk penyandang disabilitas.

\section{HASIL DAN PEMBAHASAN}

\subsection{Analisis Deskriptif}

Analisis bangunan terhadap 11 pertimbangan utama akses disabilitas dari Australian Disability Clearinghouse on Education and Training yang harus disediakan dalam hal aksesibilitas. (ADCET, 2019)

Pertama yaitu untuk peta jalan untuk disabilitas, Campus Map belum memiliki data ini, dimana direktori menunjukkan area mana saja yang bisa di akses oleh penyandang disabilitas fisik (pintu masuk disabilitas, toilet) 


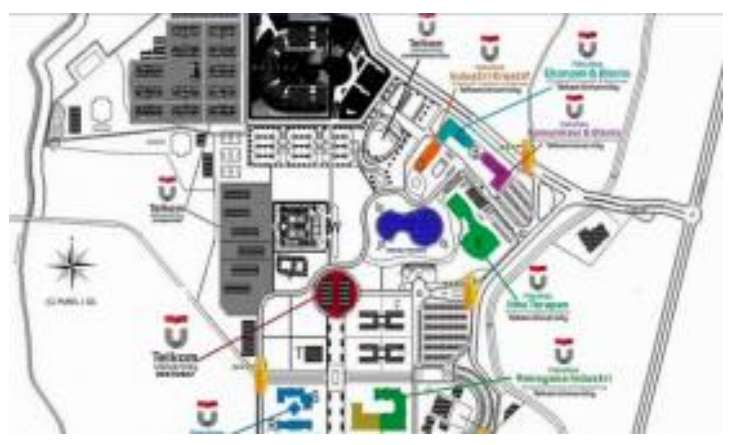

Gambar 6. Peta Kampus Telkom University Sumber: Igracias Telkom University website.

Sebagai perbandingan sebaiknya peta jalan dibuat seperti Peta Kampus dari University of Florida yang memiliki info pintu untuk disabilitas, area parkir disabilitas dan rute untuk disabilitas.

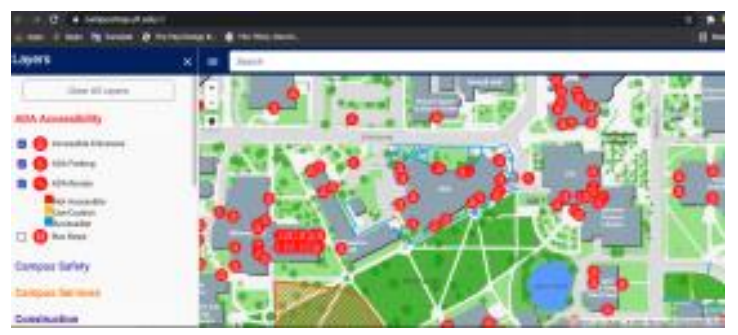

Gambar 7. Peta Kampus University of Florida Sumber: University of Florida website

Kedua yaitu untuk jalur untuk disabilitas (di luar gedung). pada gedung FIK masih belum ada jalur perjalanan yang jelas dan menerus untuk disabilitas fisik ke titik masuk utama kampus dari transportasi umum atau tempat parkir. Jalur pedestrian yang ada masih kurang lebar bagi orang yang menggunakan kursi roda / alat bantu berjalan / alat bantu mobilitas untuk melewati orang lain / kurang dari 120 meter

Ketiga yaitu signage, signage untuk penanda pengguna disabilitas di FIK hanya ada satu penanda di halaman parkir yaitu signage untuk parkir disabilitas.

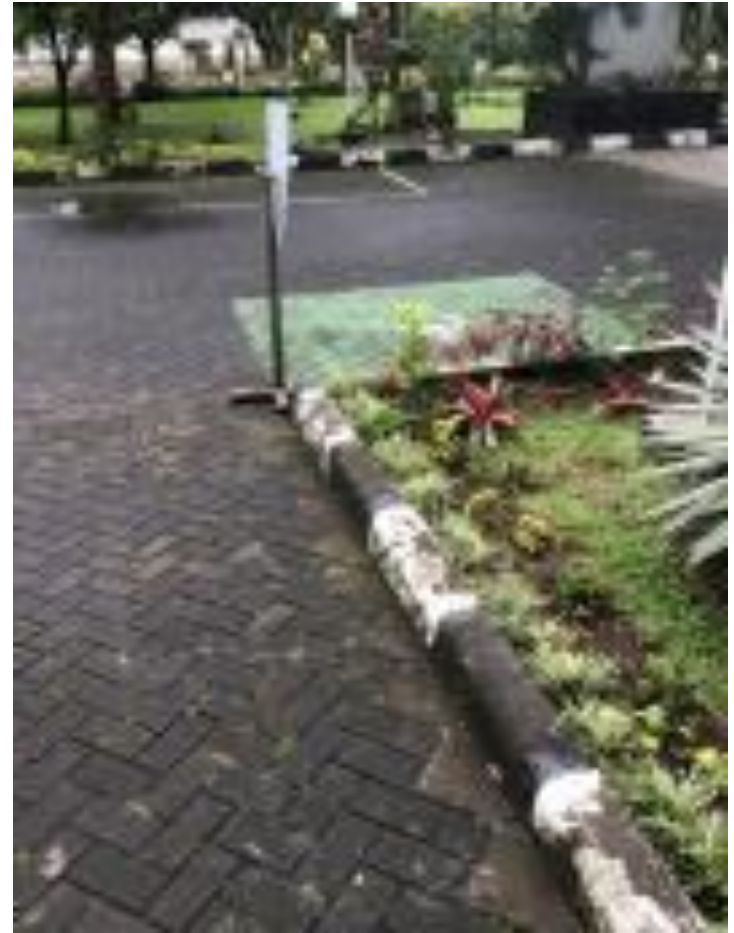

Gambar 8. Signage Parkir disabilitas

Ke empat adalah jalur untuk disabilitas (dalam gedung). Lorong/hallway cukup lebar untuk orang yang menggunakan kursi roda, alat bantu jalan atau alat bantu mobilitas lainnya untuk berbelok atau melewati orang lain (lebar lorong di gedung FIK sekitar 2 meter)

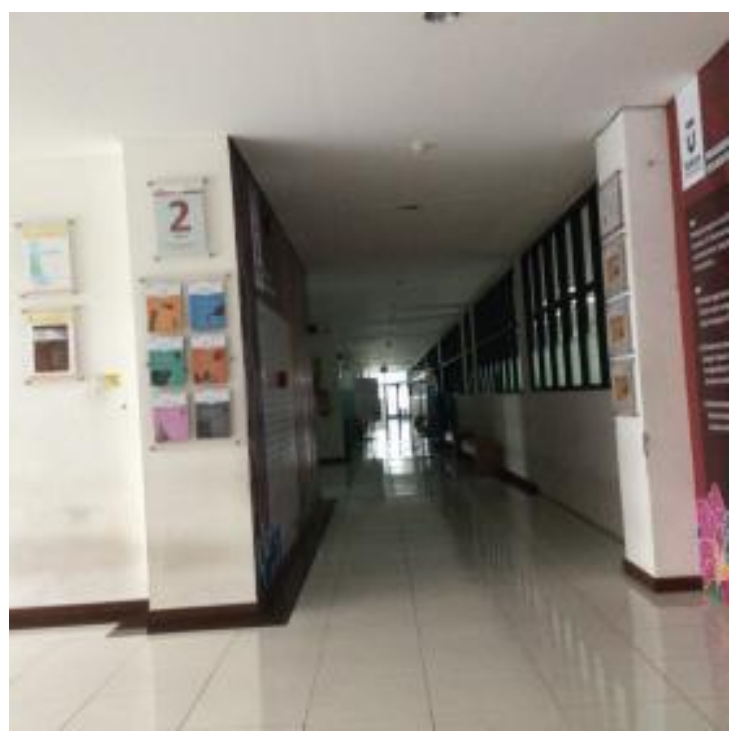

Gambar 9. Lorong di gedung FIK

Pada gedung ini tidak menggunakan pintu otomatis untuk akses keluar-masuk. Pintu utama terbuat dari kaca tanpa frame dan berat, dari segi keamanan tidak baik untuk pengguna kursi roda. 


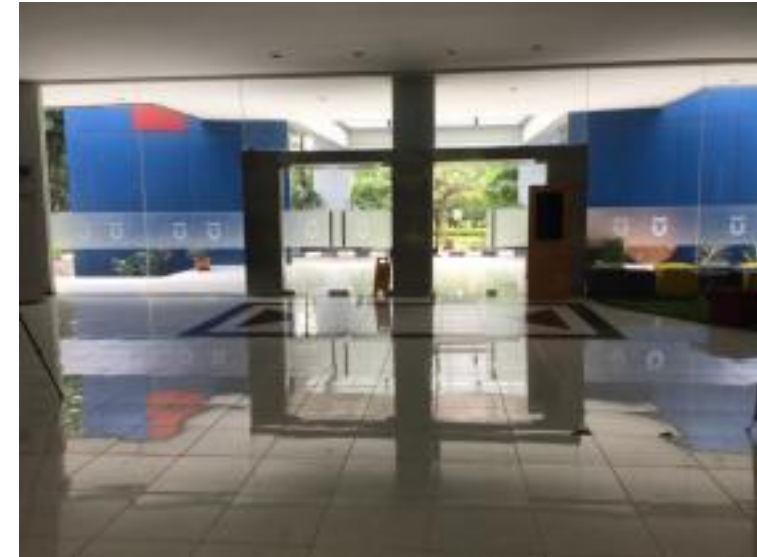

Gambar 10. Pintu utama di gedung FIK

Untuk akses pintu masuk ke ruangan kelas menggunakan pintu tarik dan dorong manual, serta lebar aksesnya kurang dari $80 \mathrm{~cm}$.

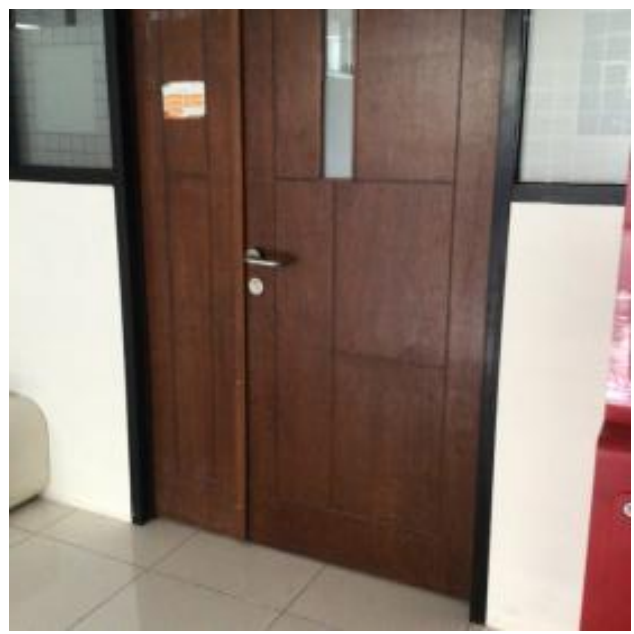

Gambar 11. Pintu masuk ke kelas di Gedung FIK

Kelima adalah adalah fasilitas untuk akses vertikal yaitu tangga, lift dan ramp. Untuk akses vertikal pada tangga, sudah memiliki persyaratan berikut ini: handrail yang tidak terputus, warna strip kontras di tepi depan dan tidak ada anak tangga terbuka.

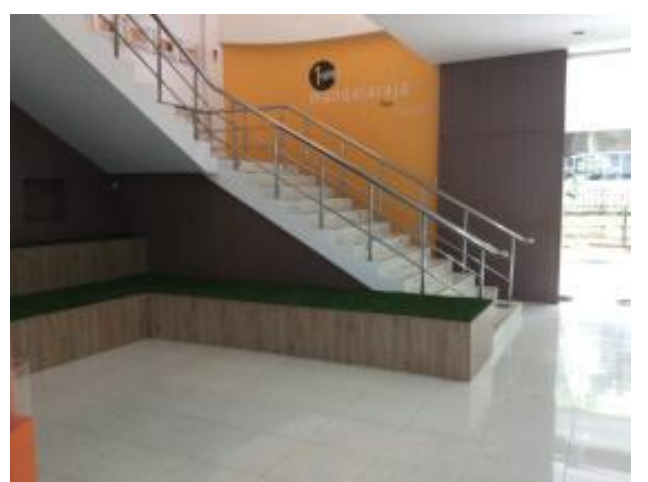

Gambar 12. Tangga utama di gedung FIK

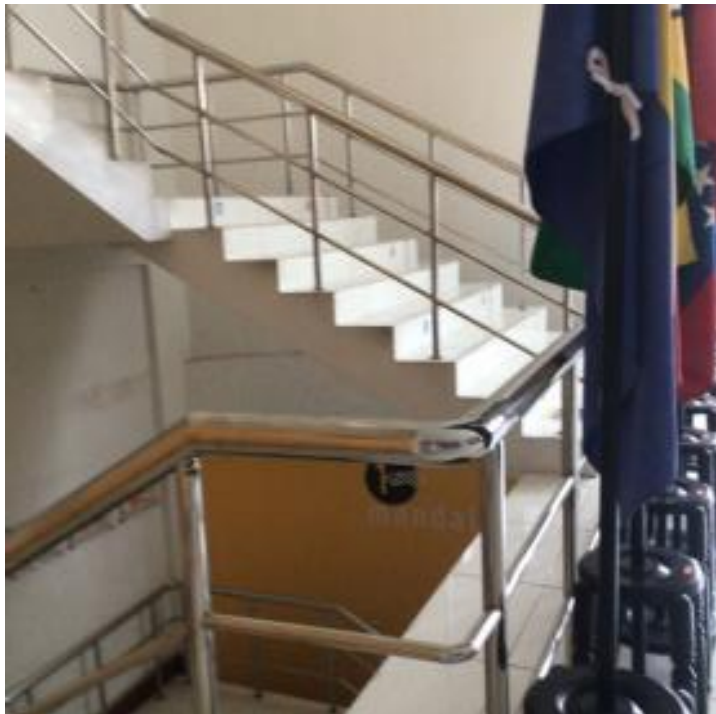

Gambar 13. Tangga lantai 2 ke lantai 3 di gedung FIK

Lift di gedung FIK tidak memungkinkan seseorang yang menggunakan kursi roda atau alat bantu jalan untuk masuk dan berputar untuk mengakses panel kontrol lift. Ukuran pintu lift di FIK sendiri hanya $80 \mathrm{~cm}$.

Untuk penempatan tombol lift di ketinggian yang dapat dijangkau oleh pengguna kursi roda.

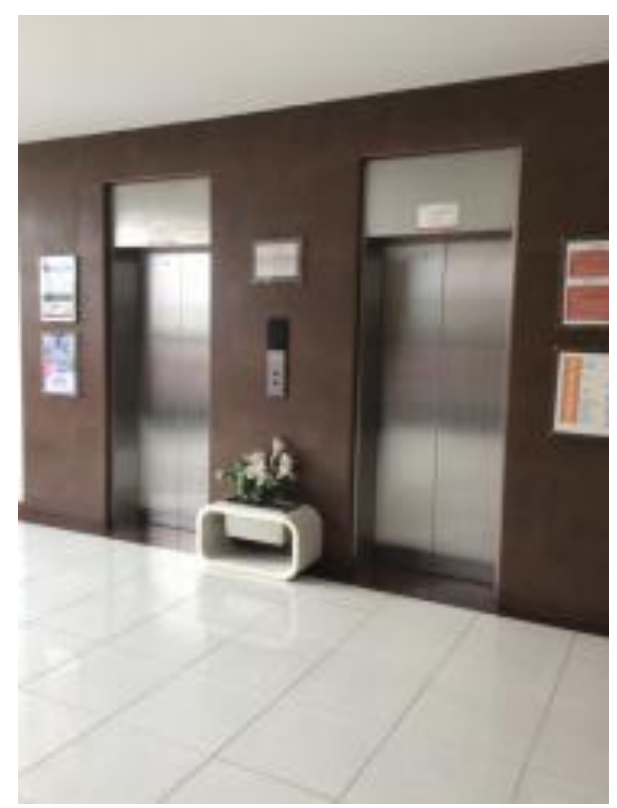

Gambar 14. Lift di gedung FIK

Untuk ramp di FIK sendiri hanya ada satu di akses depan dari halaman parkir ke gedung sebatik, kemiringan ramp nya cukup landai, tidak memiliki hand rail tidak ada pengaman di lantainya. 


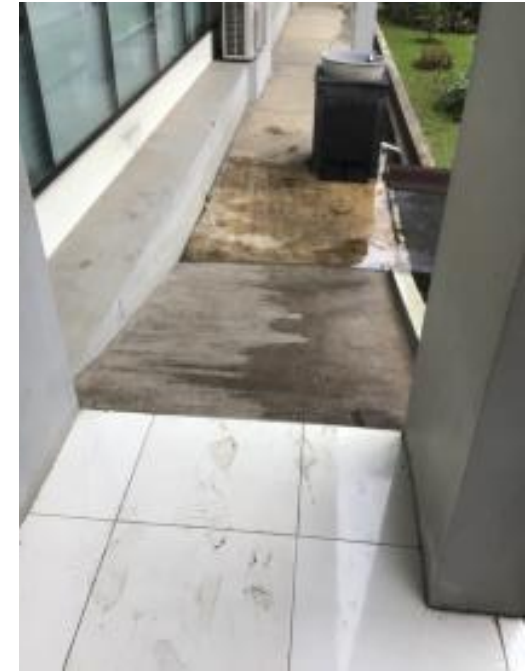

Gambar 15. Ramp di gedung FIK

Keenam dan ketujuh, merupakan hal terkait dengan ruang tempat belajar dan mengajar, dari ruang belajar yang ada di FIK, belum ada ruang khusus untuk pengguna kursi roda, misalnya bagian depan kelas yang memang khusus disediakan untuk penyandang disabilitas fisik. Pada ruang seminar atau ruang pengajaran kapasitas besar dengan fixed seating, tidak tersedia ruang untuk mahasiswa yang menggunakan kursi roda.

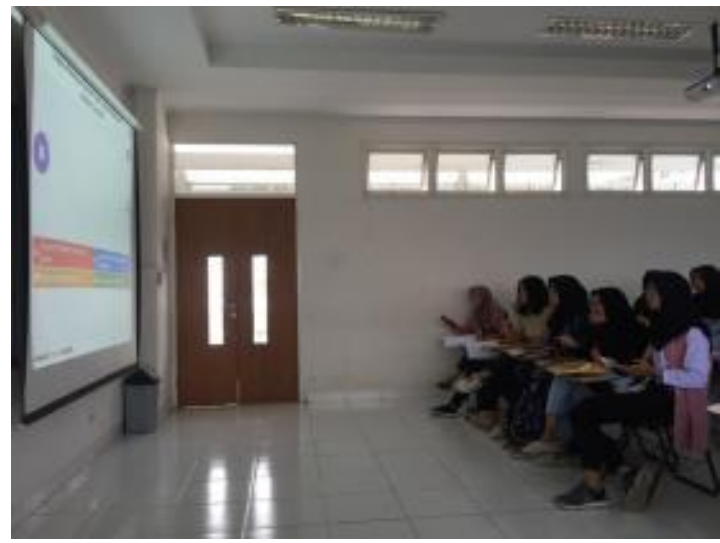

Gambar 16. Kursi Kuliah yang menyatu dengan meja tidak ramah untuk pengguna kruk atau kursi roda

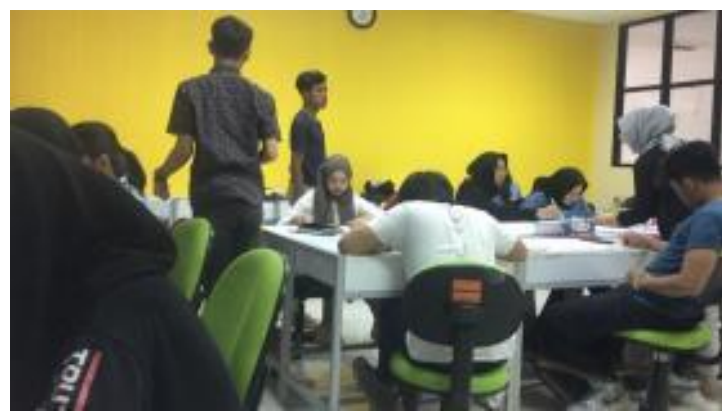

Gambar 17. Furniture di ruang studio FIK
Kedelapan yaitu furniture yang memfasilitasi para penyandang disabilitas. Dari keseluruhan furniture tidak ditemukan Tidak adanya furniture yang bisa di adjust/ disesuaikan ketinggiannya untuk kebutuhan pengguna kursi roda. Tetapi dari standar ketinggian meja untyk pengguna kursi roda yaitu sekita $70-86$ $\mathrm{cm}$, meja pengajar dan mahasiswa sudah memnuhi standar ketinggian yang cukup.

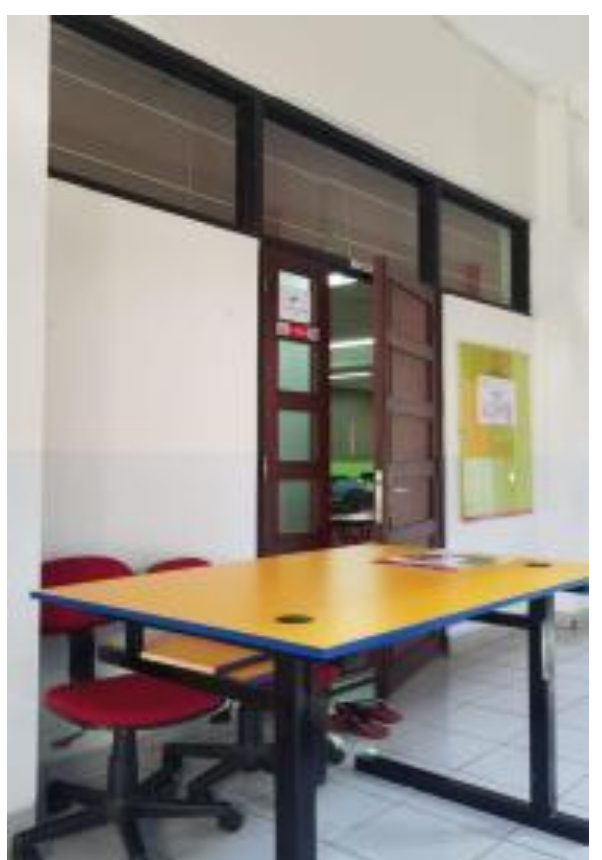

Gambar 18. Meja yang tidak bisa di sesuaikan ketinggiannya

Kesembilan adalah fasilitas umum yaitu toilet. Hasil pengamatan untuk fasilitas kamar mandi di FIK untuk penyandang disabilitas belum memiliki hal - hal berikut ini: Pintu otomatis atau mudah untuk membuka / menutup, ruang sirkulasi yang cukup untuk masuk dan berputar, ruang yang cukup di sekitar toilet untuk menampung perpindahan sisi kiri atau kanan, peralatan / fasilitas pada ketinggian yang sesuai misalnya grabrail, keran, cermin, pengering tangan, Luasan bilik dan akses masuk toilet belum ada yang menyesuaikan kebutuhan disabilitas fisik, bilik toilet lebarnya hanya sekitar $75-80 \mathrm{~cm}$

Tetapi FIK sendiri sudah memiliki fasilitas kamar mandi yang cukup mudah diakses yang terletak di / dekat gedung kampus sehingga orang tidak harus menempuh perjalanan jauh untuk mengaksesnya. Toilet ada di setiap lantai. di lantai dasar sebelah kanan lobby. Di lantai 2, 3, 4 berada di sebelah kiri lobby 


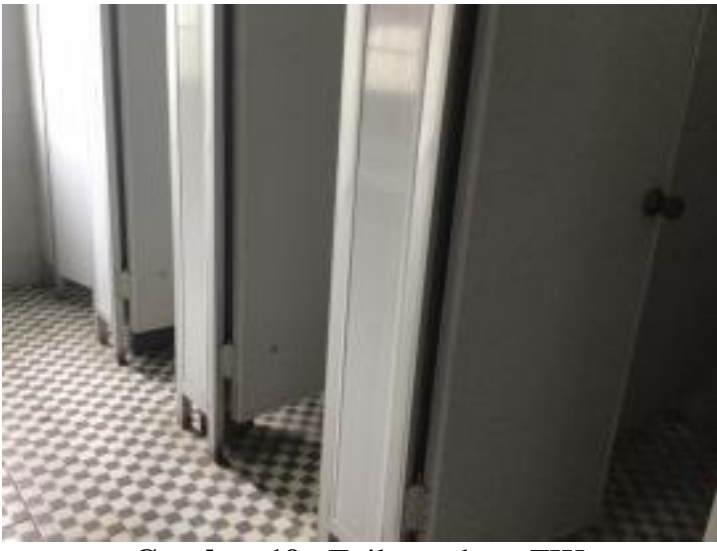

Gambar 19. Toilet gedung FIK

Selain itu lobby dan ruang tunggu di FIK dari segi penggunaan penutup lantai yang belum memperhatikan pengguna kursi roda, dimana ada perbedaan material lantai yang keras (lantai) dan lunak (karpet) akan berdampak pada mobilitas pengguna kursi roda.

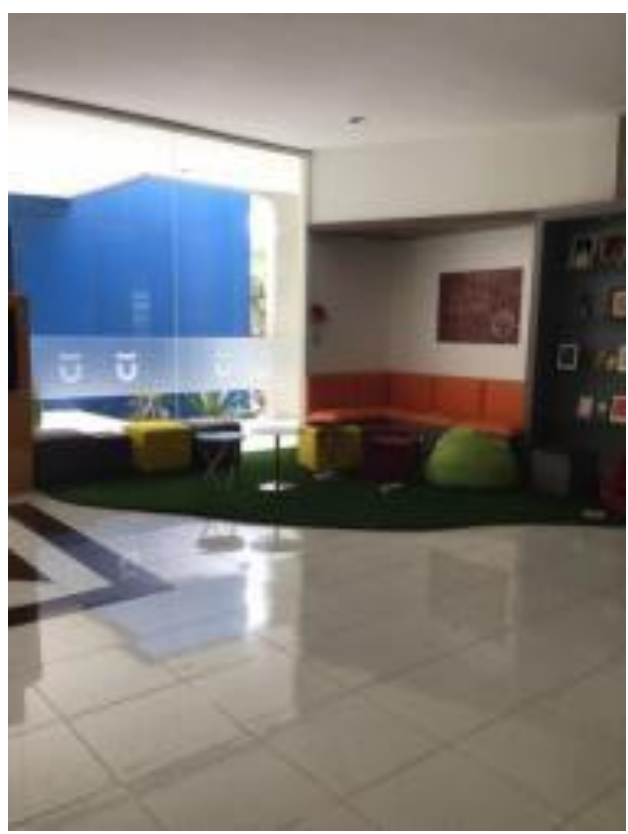

Gambar 20. Lobby gedung FIK

Kesepuluh yaitu prosedur darurat yang memadai untuk para penyandang disabilitas. Untuk prosedur darurat rencana evakuasi kampus belum mencakup ketentuan untuk penyandang disabilitas. Dalam hal ini guiding rail untuk penyandang disabilitas fisik belum ada, dan juga akses di tangga darurat yang tidak mungkin bisa dipakai pemakai kursi roda.

Yang terakhir adalah bagaimana cara mengkomunikasikan kepada para penyandang disabiltas jika akses jalan mereka terhambat ketika ada pembangunan atau acara yang menghalangi akses. Di FIK sendiri sejauh ini belum memiliki cara atau rencana untuk menghadapi hal ini.

\subsubsection{Hasil Survey Kebutuhan Disabilitas Fisik}

Dari hasil pengamatan kebutuhan akan fasilitas penyandang disabilitas di lingkung FIK Telkom University masih belum memenuhi 11 kriteria ramah disabilitas menurut ADCET. Hampir semua kriteria belum difasilitasi oleh telkom university. Tidak adanya akses vertikal yang dibutuhkan. Kebutuhan fasilitas umum yang belum terpenuhi dan juga fasilitas untuk belajar mengajar serta semua fasilitas lainnya. kalaupun ada seperti ramp hanya sebatas ada tetapi belum memenuhi standar yang diharuskan.

Untuk memperjelas kekurangan yang ada di kampus FIK Telkom university dan mengetahui fasilitas yang paling dapat memenuhi kebutuhan kegiatan belajar penyandang disabilitas di univertas. Dilakukan penyebaran kuesioner, kuesioner disebar kepada masyarakat secara umum dan pelajar yang memiliki disabilitas fisik untuk mendapatkan kebutuhan fasilitas yang dibutuhkan untuk penyandang disabilitas.

Identitas responden, Umur responden paling banyak di umur pelajar yaitu 15 -30 tahun.

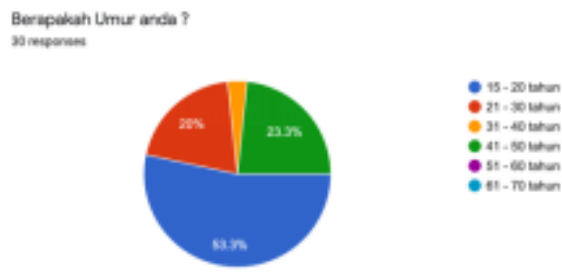

Diagram 1. Umur Responden

Jenis kelamin responden sebagian besar adalah laki-laki sebesar 63\% (diagram 2)

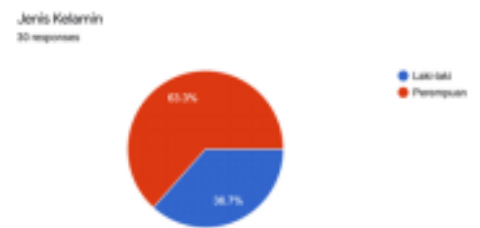

Diagram 2. Jenis kelamin responden 
Secara menyeluruh, responden menyatakan bahwa kebutuhan akan fasilitas infrastruktur bagi penyandang disabilitas fisik adalah perlu disediakan di lingkungan kampus (diagram 3)

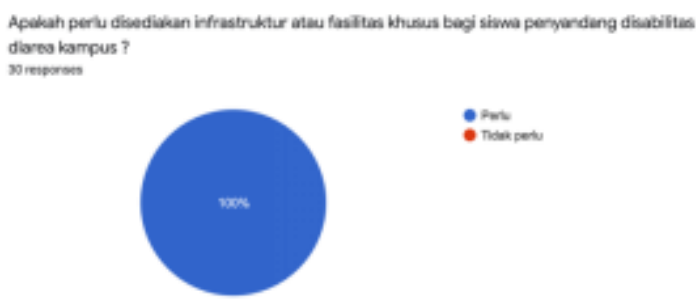

Diagram 3. Kebutuhan infrastruktur khusus bagi difabel fisik

Pembuatan jalur khusus bagi disabilitas fisik, seluruh responden menyatakan diperlukan. (diagram 4)

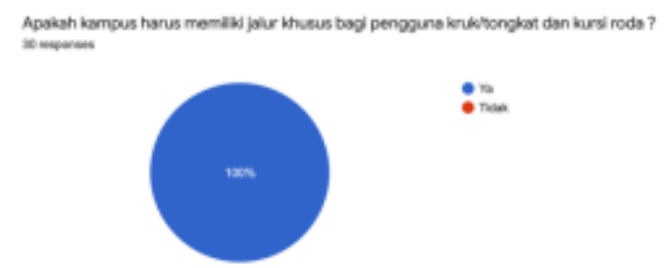

Diagram 4. Kebutuhan jalur khusus difabel fisik

Dalam setiap perbedaan tinggi lantai, hampir seluruh responden menyatakan perlu adanya ramp khusus difabel, dalam hal ini khusus bagi pengguna kursi roda. (diagram 5)

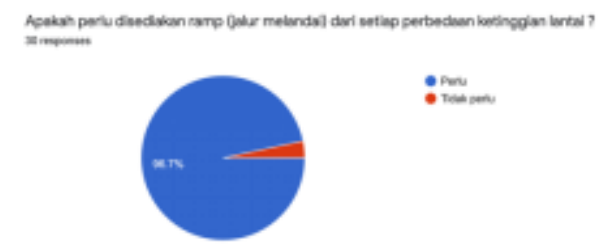

Diagram 5. Kebutuhan ramp disetiap perbedaan ketinggian lantai

Sebagian besar responden menyatakan bahwa perlunya adanya lift vertikal pada gedung kampus bertingkat (diagram 6)

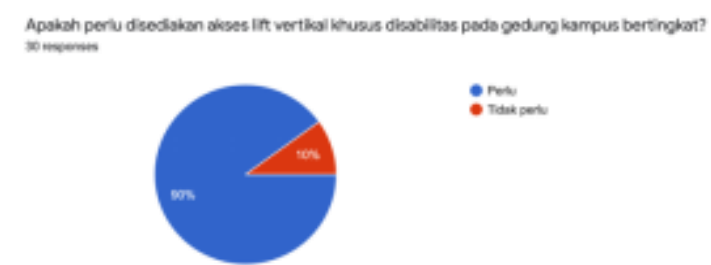

Diagram 6. Kebutuhan lift vertikal pada kampus bertingkat

Sebagian responden yaitu sebesar $60 \%$ berpendapat akan adanya kebutuhan elevator khusus kursi roda (diagram 7)

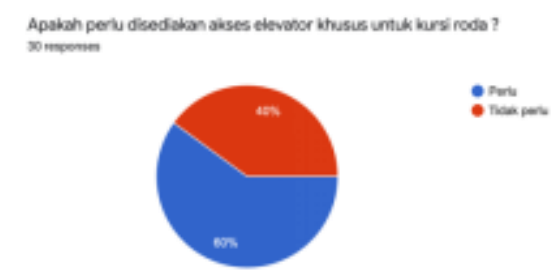

Diagram 7. Kebutuhan elevator khusus kursi roda

Ukuran pintu yang dibutuhkan harus bisa dilalui oleh pengguna kursi roda (diagram 8)

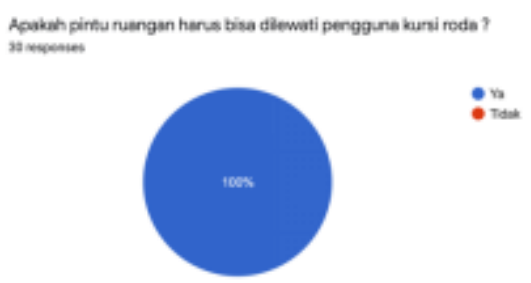

Diagram 8. Ukuran pintu khusus kursi roda

Sebagian besar responden memilih pintu geser otomatis sisanya memilih pintu geser manual dan tidak ada responden yang memilih pintu ayun manual (diagram 9)

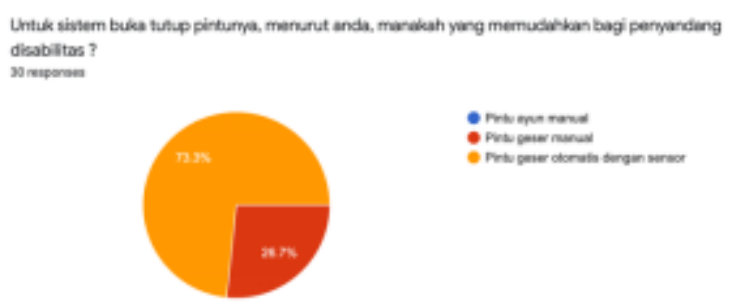

Diagram 9. Kebutuhan sistem buka tutup pintu

Sebagian besar responden menyatakan bahwa perlunya meja khusus pengguna kursi roda (diangram 10)

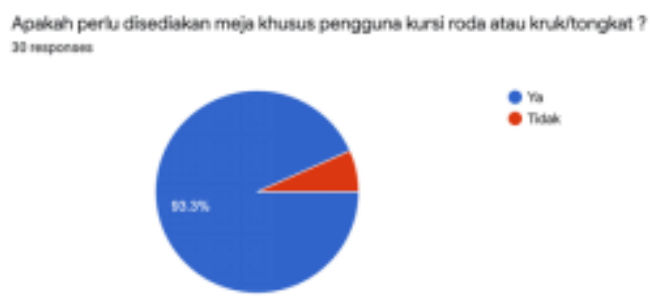

Diagram 10. Kebutuhan meja khusus 
Seluruh responden menyatakan perlu disediakan toilet khusus pengguna penyandang disabilitas fisik. (diagram 11)

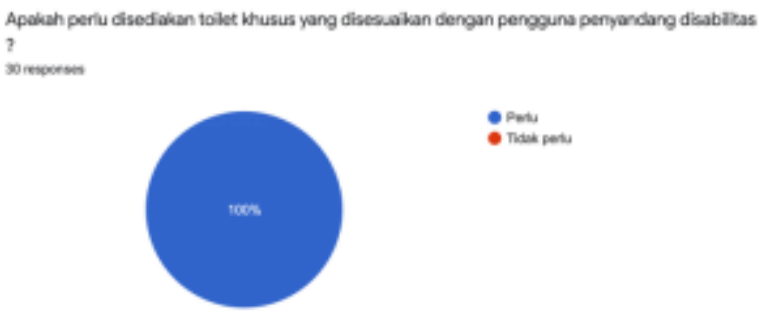

Diagram 11. Kebutuhan toilet bagi difable fisik

Dari respon untuk sistem penguncian toilet paling besar memilih menggunakan sensor otomatis dan sistem tombol digital (diagram 12)

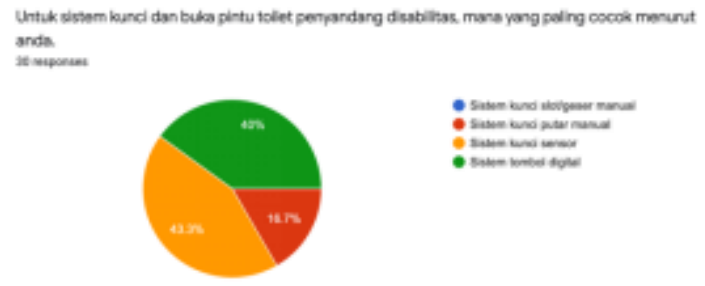

Diagram 12. Kebutuhan sistem penguncian pintu toilet bagi difabel fisik

Sebagian besar responden menyatakan membutuhkan papan atau lampu petunjuk keadaan darurat. (diagram 13)

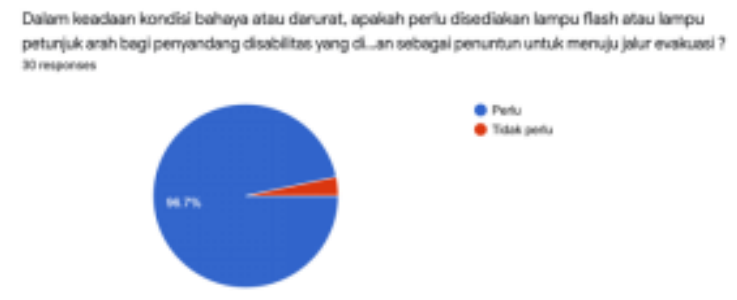

Diagram 13. Kebutuhan papan atau lampu petunjuk keadaan darurat

Seluruh responden menyatakan butuh adanya signage / simbol-simbol khusus terkait tempat untuk disabilitas (diagram 14)

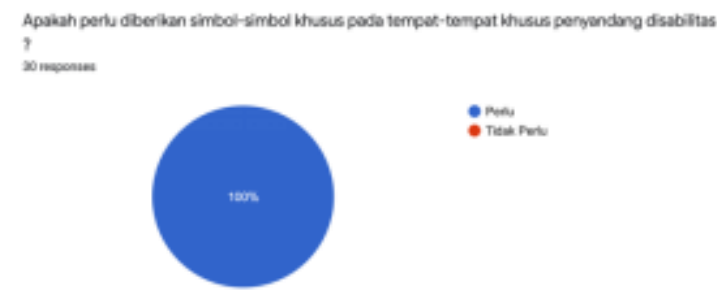

Diagram 14. Kebutuhan simbol khusus difabel

\subsubsection{Temuan Hasil Observasi Lapangan dan survey}

Dari hasil sebaran kuesioner fasilitas yang membantu penyandang disabilitas dapat disimpulkan bahwa kebutuhan akan kemudahan akses yang paling banyak dibutuhkan. Seperti yang juga hasil dari penelitian di universitas Brawijaya untuk kebutuhan aksesibilitas di kampus yang memang dibutuhkan mencakup, sarana hubungan horizontal antar ruang yang meliputi, pintu, selasar, koridor, jalur pedestrian, jalur pemandu dan jembatan penghubung antar ruang. Pintu geser otomatis merupakan pintu yang paling memenuhi kriteria kemudahan, keselamatan dan kemandirian (Jefri, 2016). Jika disimpulkan dari hasil survey penyandang disabilitas yang pertama dibutuhkan adalah akses yang baik baik dari segi luasan dan kemudahan. Seperti pintu otomatis lebih banyak dipilih dibandingkan dengan pintu geser manual atau pintu ayun manual. Untuk akses vertikal, lift untuk penyandang disabilitas lebih banyak dipilih dibandingkan dengan tangga / elevator khusus untuk penyandang disabilitas fisik. Secara infrastruktur hampir semua memilih akan butuhnya fasilitas yang dibutuhkan oleh para penyandang disabilitas fisik, seperti ramp, akses luasan yang mencukupi begitu juga untuk kemudahan ketika dalam keadaan darurat.

Dan juga mengikuti regulasi dari pemerintah tentang Penerapan Prinsip Desain Universal Dan Penggunaan Dasar Ruang Yang Memadai, dimana harus memenuhi persyaratan kemudahan hubungan horizontal antar ruang (Kementrian Pekerjaan Umum Dan Perumahan Rakyat, 2017).

\section{KESIMPULAN}

Dari data - data yang didapatkan dari pengamatan dan hasil survey, observasi dan dokumentasi secara garis besar temuan yang diperoleh adalah:

Akses inter-space di FIK Telkom University cukup memfasilitasi dengan luasan dan infrastruktur yang sudah ada. Tetapi bisa didukung lagi dengan penggunaan ramp yang lebih baik dengan adanya hand railing dan pengaman dibagian lantainya. Tetapi untuk 
akses antar ruang masih banyak yang belum memfasilitasi.

Untuk inter - floor mobility facilities yang paling diminta oleh responden adalah penggunaan lift, Lift yang tersedia di FIK belum memnuhi persyaratan karena dimensinya yang terlalu kecil untuk pengguna kursi roda

Untuk fasilitas belajar di kelas dan ruang seminar seperti yang diminta oleh keseluruhan responden untuk terfasilitasi seperti adanya meja yang dapat di adjust ketinggiannya belum terdapat di FIK Telkom university

Untuk fasilitas umum yang dibutuhkan seperti toilet belum memenuhi standar luasana untuk pengguna kursi roda. Dan hand railing untuk membantu mobilisasi pengguna alat bantu jalan dan kursi roda

Untuk mendapatkan keseluruhan kebutuhan penyandang disabilitas fisik, banyak yang harus diganti secara struktur bangunan. (lift dan akses pintu masuk yang memenuhi luasan pengguna kursi roda)

Untuk mencapai kampus inklusi tentunya tidak mudah karena berhubungan dengan struktur dan infrastruktur universitas. Kampus inklusi juga tidak hanya sebatas di disabilitas fisik cakupannya sangat luas mencakup keseluruhan disabilitas seperti, tuna rungu, tuna netra dan tuna wicara.

Untuk itu secara bertahap untuk mewujudkan kampus inklusi bisa dimulai dari menyiapkan sarana dan prasarana yang mendukung kampus inklusi. Dengan mewadahi mobilisasi mahasiswa dengan disabilitas fisik dari mulai akses kampus dari pintu masuk sampai ke ruang kelas harus mendukung berseta kebutuhan selama di ruang kelas

Kesesuaian untuk mencapai kampus yang ramah disabilitas fisik masih harus banyak dibenahi dan penyedian fasilitas nya harus ditambah. Penggunaan atau penerapan teknologi bisa membantu untuk mencapai kampus yang ramah disabilitas.

\section{UCAPAN TERIMAKASIH}

Penelitian ini dilakukan dengan dukungan dari Telkom University. Ucapan terimakasih diucapkan untuk para pihak yang membantu pengisian kuesioner sehingga membantu tercapainya data yang dibutuhkan.

\section{REFERENSI}

ADCET. (2019) Higher education statistic. [Online] Available from:

1 [Diakses pada: 15 September 2020].

Aziz, S. (2014). Perpustakaan Ramah Difabel: Mengelola Layanan Informasi bagi

Pemustaka Difabel. Yogyakarta: Ar-Ruzz Media.

Dzulfikar, L. (2019). The long road for disability-inclusive education in Indonesia's universities. [Online] Available from: https://theconversation.com/the-longroad-for-disability-inclusive-education-inindonesias-universities-128224 [Diakses 12 September ]

Hikmah, T.L, Yusuf, M., Sianturi, R.S. (2020) Kriteria Pengembangan kampus Ramah Disabilitas di Universitas Airlangga. Jurnal Tehnik ITS. 09(2).

Jefri, T. (2016). Aksesibilitas Sarana Dan Prasarana Bagi Penyandang Tunadaksa Di Universitas Brawijaya. IDJS, 03(1), 16-25

Kementrian Kesehatan Republik Indonesia. (2019). DISABILITAS. Kementrian Kesehatan Republik Indonesia, Pusat Data Dan Informasi. Jakarta: Kementrian Kesehatan Republik Indonesia.

Kementrian Pekerjaan Umum Dan Perumahan Rakyat. (2017). PERSYARATAN KEMUDAHAN BANGUNAN GEDUNG. Jakarta, Indonesia.

Kementrian PUPR. (2016). Pengarusutamaan Gender Kementerian Pekerjaan Umum dan Perumahan Rakyat. [Online] Available from: https://pug-pupr.pu.go.id: https://pug-

pupr.pu.go.id/_uploads/PP/UU.\%20No.\%

208\%20Th.\%202016.pdf [Diakses 12 September 2020]

Primastika, W. (2018). Penyandang Disabilitas Masih Sulit Mengakses Perguruan Tinggi. [Online] Available from: https://tirto.id/penyandang-disabilitasmasih-sulit-mengakses-perguruan-tinggic6am [Diakses 12 September 2020] 
Centre of Excelence in Universal Design.

(2019) Building for Everyone [Online]

Available

from:

"http://universaldesign.ie/Built-

Environment/Building-for-

Everyone/Entire-Series-Books-1_10.pdf"

http://universaldesign.ie/Built-

Environment/Building-for-

Everyone/Entire-Series-Books-1 10.pdf

[Diakses pada: 15 September 2020]. 